\title{
Seed production in sideoats grama populations with differ- ent grazing histories
}

\author{
STEVEN E. SMITH, REBECCA MOSHER, AND DEBRA FENDENHEIM
}

Authors are associate professor, School of Renewable Natural Resources, University of Arizona, Tucson, Ariz. 85721; graduate student, University Program in Genetics, Duke University, Durham, N.C. 27706; and research specialist, School of Renewable Natural Resources, University of Arizona, Tucson, Ariz. 85721 .

Abstract

Frequent and intense defoliation of grasses has been associated with the evolution of "grazing morphotypes" that exhibit a variety of vegetative traits correlated with improved grazing resistance. While recovery from a seed bank is not considered an important grazing resistance mechanism, relatively little is actually known regarding seed (caryopsis) production in grazing morphotypes of caespitose grasses. The goal of this research was to compare components of seed production in 2 populations of sideoats grama (Bouteloua curtipendula var. caespitosa Gould \& Kapadia) from nearby sites with different histories of livestock grazing. This was done using vegetative propagules of genotypes from both populations in a greenhouse study. The study was conducted in $\mathbf{2}$ flowering seasons under conditions considered favorable for seed production. The population exposed to livestock grazing showed a genetically based decrease in seed production relative to the ungrazed population. Lower seed production per plant in the grazed population was at least partially due to reduced numbers of tillers and panicles per plant and spikes per panicle that may be associated with selection for grazing tolerance. The grazed population also exhibited lower average seed production per spike indicating lower inherent floral fertility. Seed production was not closely correlated with vegetative traits associated with increased grazing tolerance, nor was there evidence of obvious physiological trade-offs related to decreased seed production in the grazed population. Lower seed production potential in populations of sideoats grama intensively grazed by livestock may lead to reduced potential for seedling colonization.

Key Words: Bouteloua, defoliation tolerance, evolution, grazing resistance

Grasses that are exposed to herbivores often possess unique life history, morphological and physiological traits (Carmen and Briske 1985, Briske and Richards 1995, Briske 1996). When defoliation has been frequent over long periods of time, these traits may be associated with the evolution of genetically based defoliation tolerance and the emergence of "grazing morphotypes" in the plant populations affected (e.g., Detling and Painter

Research was supported by the University of Arizona Foundation and the Arizona Agricultural Experiment Station. Authors wish to thank Lyman Nyquist for assistance in statistical analysis, Virgil Mercer for access to collection sites and information on their history, and Sharon Biedenbender, Mitchel McClaran, Bruce Munda, Mark Pater, and David Williams for technical assistance.

Manuscript accepted 1 Jan. 2000.
Resumen

La frecuente e intensa defoliación de los zacates ha sido asociada con la evolución de "morfotipos de apacentamiento" que presentan una variedad de características vegetativas correlacionadas con una mejor resistencia al apacentamiento. Mientras que la recuperación a partir del banco de semillas no se considera un mecanismo importante de resistencia al apacentamiento, actualmente poco se sabe respecto a la producción de semilla (cariópside) de los "morfotipos de apacentamiento" de zacates cespitosos. La meta de este estudio fue comparar los componentes de la producción de semilla de dos poblaciones de "Sideoat grama" (Bouteloua curtipendula var. caespitosa Gould y Kapadia) de sitios cercanos con diferentes historiales de apacentamiento por ganado. Esto se realizó a través de en un estudio de invernadero utilizando propágulos vegetativos de genotipos de ambas poblaciones. El estudio se condujo durante 2 estaciones de floración bajo condiciones consideradas favorables para la producción de semilla. La población expuesta al apacentamiento por ganado mostró una disminución (genéticamente basada) en la producción de semilla en relación a la población sin apacentamiento. La baja producción de semilla por planta de la población con apacentamiento se debió parcialmente a el reducido número de hijuelos y panículas por planta y espigas por panícula, lo que puede estar asociado con la selección por tolerancia al apacentamiento. La población apacentada también exhibió un promedio menor de producción de semilla por espiga, indicando una menor fertilidad floral inherente. La producción de semilla no se correlaciono estrechamente con las características vegetativas asociadas con el aumento en la tolerancia al apacentamiento, ni hubo evidencia obvia de cambios fisiológicos relacionados con la disminución de producción de semilla de la población apacentada. La potencial baja producción de semilla de poblaciones de "Sideoat grama" apacentadas intensivamente puede conducir a una reducción potencial de colonización por plántulas.

1983, Aarssen and Turkington 1985, Carmen and Briske 1985, Painter et al. 1989, 1993, Smith 1998 ). Defoliation tolerance in caespitose grasses is commonly correlated with a series of vegetative traits including reduced plant height, a less upright growth form, fewer and smaller leaves, and increased tiller number (Briske 1996).

Previous research (Smith 1998) compared vegetative responses under varying defoliation regimes of genotypes from 2 populations of sideoats grama (Bouteloua curtipendula var. caespitosa Gould \& Kapadia) with different livestock grazing histories. In 
these studies, a population with long-term exposure to cattle grazing (approximately $100 \mathrm{yr}$ ) exhibited traits associated with improved defoliation tolerance (primarily increased tiller survival and reduced tiller mass) compared to a population that was not exposed to grazing by livestock. Evidence of reduced genetic variation within the grazed population was also noted for various vegetative traits associated with defoliation tolerance. While the environments the 2 populations inhabited differed in ways other than the presence of livestock, the response of genotypes from both populations was consistent with the evolution of increased grazing tolerance in the population from the grazed site.

Increased seed production and expansion of a soil seed bank may represent an additional defoliation resistance mechanism (Briske 1996), but the effects of livestock grazing on the evolution of this resistance mechanism are not well characterized. Reduced production of reproductive tillers has been observed in populations of perennial grasses derived from sites exposed to contrasting grazing regimes (e.g., Trlica and Orodho 1989, Painter et al. 1989, 1993). Nevertheless, little information is available regarding any differences in seed (caryopsis) production between such populations. Scott and Whalley (1984) found that the mean number of seeds produced per inflorescence was significantly lower in genotypes from populations of 2 species of Danthonia that had been exposed to heavy grazing by sheep compared to relatively less grazed populations. However, protection from livestock grazing for more than 50 years did not result in altered seed production in Indian ricegrass (Achnatherum hymenoides (Roemer \& J.A. Schultes) Barkworth) genotypes taken from grazed or ungrazed sites when these genotypes were grown in a common environment (Orodho et al. 1998). A lack of additional data on seed reproduction and the evolution of grazing morphotypes prevents a more integrated understanding of demographic processes that may be affected by the presence of grazing animals.

The primary objective of this research was to determine whether exposure to different livestock grazing regimes is associated with genetically based changes in seed production in sideoats grama. This was done under conditions of minimal defoliation stress using genotypes from 2 populations with contrasting livestock grazing histories (Smith 1998). Secondary objectives were to determine whether variation in seed production was associated with other traits related to defoliation tolerance.

\section{Materials and Methods}

This research utilized genotypes from 2 populations of sideoats grama from the semidesert grassland biotic community in southeastern Arizona (Brown 1994). One population ("ungrazed") occurs atop a steep-walled butte $\left(32^{\circ} 42^{\prime} \mathrm{N}, 110^{\circ}, 2^{\prime} \mathrm{W}\right.$ $1,655 \mathrm{~m}$ asl) near Mammoth, Ariz. that probably has never been grazed by large (>100 kg) herbivores, including most domestic livestock (Hadley et al. 1991). The other ("grazed") population occurs on a site (1,338 $\mathrm{m}$ asl) that has been regularly grazed by cattle since before 1900 (V. Mercer, Mammoth, Ariz., personal communication) that is located $4.8 \mathrm{~km}$ from the ungrazed population. Deer (Odocoileus spp.) and small mammalian herbivores are able to reach both sites and may graze on sideoats grama (Krausman et al. 1997). Prairie dogs (Cynomys spp.) occurred in southeastern Arizona (Hoffmeister 1986) and may have also grazed on both sites until about the late 1930's. No description of fire history or precipitation is available for either site. Both sites are on 20-35\% slopes with numerous rock outcrops and shallow Haplargid soils (D. Robinett, USDA-NRCS, Tucson, Ariz., personal communication). Sideoats grama occurs sporadically in the area between the 2 sites, most commonly in drainages on the slopes of the butte, and this may permit gene flow between the populations.

Twenty randomly selected genotypes (basal area $>15 \mathrm{~cm}$ ) were dug from along a 400-m transect at each site in 1994. Individual genotypes were separated by at least $3 \mathrm{~m}$ and were assumed to represent the products of separate established seedlings. Genotypes from both populations are high polyploids with $2 \mathrm{n}=75-92$ (D. Showalter, University of Arizona, unpublished data, Gould and Kapadia 1964). These genotypes were grown in 4liter pots in a shadehouse in Tucson, Ariz. for 6 mo before a minimum of 6 ramets were established for each genotype from single rooted tillers (Smith 1998). Individual ramets were grown in 4-liter pots in an evaporatively cooled greenhouse and treated uniformly until June 1997 with defoliation $5 \mathrm{~cm}$ above the soil surface every 6 to 12 weeks. The resulting ramets were placed on greenhouse benches using a modified split-plot arrangement with 4 replications with population as the main plot and all 20 genotypes from each population placed randomly as sub plots within the main plots. Ramets within each main plot were grouped together within an area of $1 \mathrm{~m}^{2}$ to concentrate pollen from that population and were isolated from the other main plot in that replication or from other replications by at least $80 \mathrm{~cm}$.

Mean daily temperature in the greenhouse during the study was $32.7^{\circ} \mathrm{C}$ (mean low of $27.7^{\circ} \mathrm{C}$, mean high of $35.6^{\circ} \mathrm{C}$ ). Fans were used to circulate pollen during anthesis. Ramets were irrigated individually when leaf curling and color indicated drought stress. Soil moisture content was $\sim 20$ to $30 \%$ of field capacity at this point.

Ramets were allowed to grow from June through October in 1997 and 1998, a period exceeding the entire flowering season for sideoats grama in southern Arizona. Inflorescences in sideoats grama are panicles with up to 50 short, pendulous spikes. As panicles matured, at least 3 were harvested individually from each ramet in each main plot. Spikes were counted for each panicle and individual seeds per panicle determined following threshing. Mean seed mass was determined from 50-seed samples dried at room temperature. The mean number of spikelets per spike was determined by dissecting 5 spikes from each ramet. Spikelets were assumed to contain 1 floret (Cronquist et al. 1977). Tiller number was recorded for each ramet 8 weeks after defoliation in a regrowth cycle that began 5 June 1998. Tillers that showed any sign of a mature spike were counted as reproductive.

Some of the genotypes used in this study were also included in a greenhouse study that evaluated vegetative response to different defoliation frequencies (Smith 1998). Seed production per spike in ramets from these genotypes (ungrazed: $\mathrm{N}=10$, grazed: $\mathrm{N}=9$ ) was rank correlated (Sokal and Rohlf 1995) with various traits associated with vegetative growth from the previous study where defoliation occurred every 14,28 , or 56 days over a 168 -day period. These traits were: plant height, root dry weight, shoot dry weight, total plant dry weight, and tiller number and dry weight.

Mixed-model analysis of variance was used to compare traits among genotypes of the 2 populations. Proc MIXED of SAS (Littell et al. 1996) was used with replications, years, and genotypes within populations considered random effects. For comparisons of the components of seed production (Table 1), significance of differences between populations were assessed using single-degree of freedom contrasts. Least-squares means are reported throughout for these traits. Distribution of mean seed production per spike in the 2 populations was evaluated for each year separately using frequency histograms and two- 
Table 1. Least squares means for components of seed production by structural unit in ungrazed and grazed populations of sideoats grama.

\begin{tabular}{|c|c|c|c|c|c|c|c|c|c|c|}
\hline \multirow{3}{*}{ Population } & \multicolumn{10}{|c|}{ Structural unit } \\
\hline & \multicolumn{3}{|c|}{ Spike } & \multicolumn{2}{|c|}{ Panicle } & \multicolumn{5}{|c|}{ Plant $^{1}$} \\
\hline & $\begin{array}{c}(\text { Seeds } \\
\left.\text { spikelet }^{-1}\right)\end{array}$ & $\begin{array}{l}\text { (Seeds } \\
\left.\text { spike }^{-1}\right)\end{array}$ & $\begin{array}{l}\text { (Spikelets } \\
\text { spike }^{-1} \text { ) }\end{array}$ & $\begin{array}{c}(\text { Seeds } \\
\left.\text { panicle }^{-1}\right)\end{array}$ & $\begin{array}{c}\text { (Spikes } \\
\left.\text { panicle }^{-1}\right)\end{array}$ & $\begin{array}{l}\text { (Tillers } \\
\left.\text { ramet }^{-1}\right)\end{array}$ & $\begin{array}{c}(\% \\
\text { reproductive } \\
\text { tillers) }\end{array}$ & $\begin{array}{c}\text { (Panicles } \\
\left.\text { ramet }^{-1}\right)\end{array}$ & $\begin{array}{l}\text { (Spikes } \\
\left.\text { ramet }^{-1}\right)\end{array}$ & $\begin{array}{l}\text { (Seeds } \\
\text { ramet }^{-1}\end{array}$ \\
\hline Ungrazed & $0.050^{*}$ & $0.200^{*}$ & 3.37 & $6.3^{*}$ & 31.3 & $33.7 *$ & $40.9 *$ & $9.2^{*}$ & $284^{*}$ & $55.8^{*}$ \\
\hline Grazed & $0.013^{*}$ & $0.140^{*}$ & 3.75 & $4.1^{*}$ & 28.4 & $29.2^{*}$ & $37.6^{*}$ & $6.8^{*}$ & $197 *$ & $35.1^{*}$ \\
\hline
\end{tabular}

${ }^{\mathrm{T}}$ Estimated from tiller counts made in 1998.

*Population means significantly different by single degree of freedom contrast $(\mathrm{P} \leq 0.05)$.

tailed Fisher's exact tests. The same approach was used to compare the number of spikes per panicle but data from both years were combined since means were not significantly different between years for this trait. Relationships between components of seed output could be evaluated using rank correlation coefficients which do not assume a linear relationship between the 2 variables examined (Sokal and Rohlf 1995). The numbers of seeds produced per spike and spikes produced per panicle were also rank correlated with various vegetative traits associated with response to defoliation using data from a previous study (Smith 1998) for genotypes that were included in that study and the present one. Conservative rank correlation procedures were also used in this case, again because linear relationships could not be assumed but also because data originated from separate experiments for some pairs of variables.

Genetic analysis was done using BoxCox transformed values for the number of seeds per spike (Sokal and Rohlf 1995) and untransformed values for the number of spikes per panicle. Broad-sense heritability was estimated for both traits within each population using a split-plot in time design after Nyquist (1991). When the estimates were significantly greater than 0 , standard errors were calculated using the method of Gordon (1979). Phenotypic correlations were utilized throughout since the array of genotypes and experimental design utilized did not permit accurate estimation of additive genetic variance which would be required for calculation of genetic correlations (Lynch and Walsh 1998). Statistical significance was assigned at $\mathrm{P} \leq 0.05$ in all cases.

\section{Results}

Ramets from the ungrazed population produced significantly more seeds per spikelet and spike overall than did those from the grazed population (Table 1). Since the 2 populations did not differ in the average number of spikelets per spike, the number of seeds per spike may be considered as the primary component explaining differences in floral fertility between the populations. This resulted in significantly higher mean seed production per panicle in the ungrazed population. Using tiller count data, it was possible to estimate additional components of seed output on a whole-plant basis. This showed that in the absence of significant defoliation, ramets from the ungrazed population would generally be expected to produce significantly more tillers overall and reproductive tillers, and therefore more panicles and spikes than ramets from the grazed population (Table 1). Combination of tiller data with that from individual spikes and panicles further revealed that significantly more seeds would be expected per ramet under these conditions in an entire flowering season within the ungrazed population than within the grazed population.

There was no significant difference between the populations in average seed mass (ungrazed: $0.62 \pm 0.05 \mathrm{mg}$ [leastsquares mean $\pm \mathrm{SE}]$, grazed: $0.70 \pm 0.08$ $\mathrm{mg}$ ). Because ramets from the ungrazed population would produce more seeds, the mean total mass of seeds produced per ramet was significantly higher in the ungrazed population $(34.2 \pm 5.7 \mathrm{mg})$ than
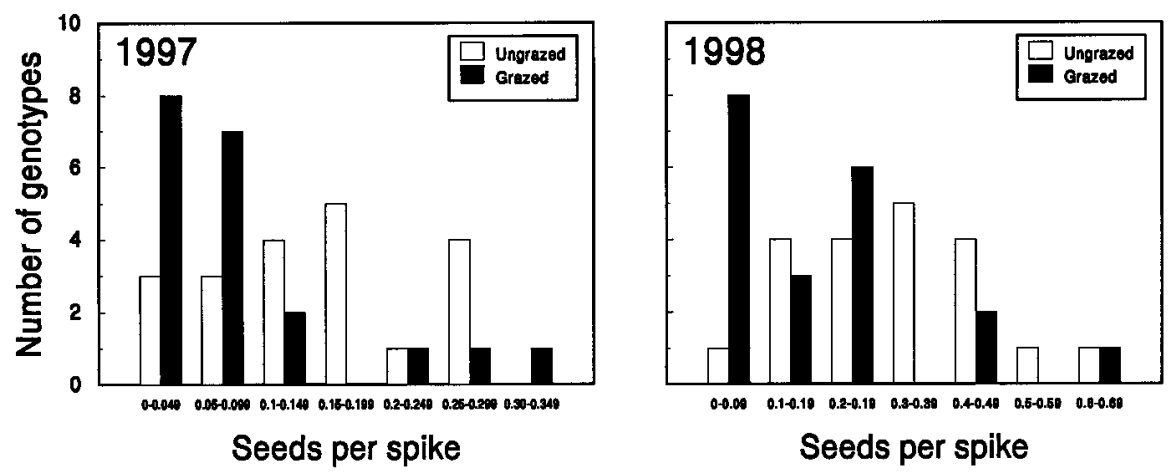

Fig. 1. Distribution of mean seed production per spike for genotypes from ungrazed and grazed populations of sideoats grama. Population distributions significantly different $(P \leq$ 0.05) based on Fisher's exact test for experiments conducted in 1997 and 1998. 
mean number of spikes per panicle did not differ between years, nor was there a significant population $\mathrm{x}$ year interaction for this trait. The distributions of this trait also did not differ significantly between populations (Fig. 2). Medians for the ungrazed and grazed populations were 31.6 and 28.6 spikes per panicle, respectively.

The number of seeds per spike was significantly and negatively correlated with the number of tillers per ramet in the ungrazed population as measured in this study (Table 2). The number of spikes per panicle was also positively correlated with tiller number in this population. Overall seed production per ramet was positively associated with the number of seeds produced per spike in both populations. In the grazed population, the number of seeds per ramet was also positively correlated with both the number of tillers and the number of spikes produced per ramet. This would be expected given the lower mean seed production per spike in this population. The average mass of an individual seed was not significantly correlated with any other primary reproductive measures in either population.

Combining data from this study with those from Smith (1998), the number of seeds produced per spike was significantly correlated only with mean tiller weight with defoliation every 28 days $\left(r_{s}=0.52\right.$, $\mathrm{P} \leq 0.05)$. No other significant phenotypic correlations were observed between any measures of reproductive output and vegetative growth under different defoliation regimes for the 19 genotypes common to both studies.

Overall variability in the number of seeds per spike appeared greater in the grazed population than in the ungrazed population $(\mathrm{CV}=84$ vs $121 \%)$. Broadsense heritability of the number of seeds per spike over years was significantly greater than 0 in both populations, but did not differ significantly between the populations (ungrazed: $24.5 \pm 6.0 \%$, grazed:
$35.8+11.3 \%)$. Broadsense heritability of the number of spikes per panicle was less than $2 \%$ and did not differ significantly from 0 in both populations.

\section{Discussion and Conclusions}

As was the case with vegetative traits (Smith 1998), this research shows that 2 sideoats grama populations from nearby sites with contrasting livestock grazing histories differed in reproductive characteristics that may be associated with plant demogra-

phy (Table 1, Fig. 1). While the grazed population displayed evidence of selection for vegetative traits associated with increased grazing tolerance in previous research, the current study indicates that this population also exhibits decreased average seed production potential per plant. Observation of significant broadsense heritability for the number of seeds per spike in both populations demonstrates a genetic basis for the variation among genotypes within these populations.

Because the 2 populations occupy environments that may differ in ways other than their livestock grazing history, it is not possible to definitely conclude that differences in reproductive biology are solely the result of exposure to livestock grazing in 1 population. For example, fire history and weather may differ at the 2 sites and could explain the differences in vegetative traits (Smith 1998) and reproductive biology between the populations. The 2 populations may have also diverged genetically before livestock were introduced to the grazed site. Nevertheless,

Table 2. Rank correlation coefficients between components of seed production ungrazed (upper values and grazed (lower) populations of sideoats grama.

\begin{tabular}{|c|c|c|c|c|c|c|}
\hline & $\begin{array}{l}\text { Spikes } \\
\text { panicle }^{-1}\end{array}$ & $\begin{array}{l}\text { Tillers } \\
\text { ramet }^{-1}\end{array}$ & $\begin{array}{l}\% \text { reproductive } \\
\text { tillers }\end{array}$ & $\begin{array}{l}\text { Spikes } \\
\text { ramet }^{-1}\end{array}$ & $\begin{array}{l}\text { Seeds } \\
\text { ramet }^{-1}\end{array}$ & $\begin{array}{l}\text { Seed } \\
\text { mass }\end{array}$ \\
\hline Seeds spike & - & $-0.50 * / 0.40$ & - & - & $0.68 * / 0.93 *$ & - \\
\hline Spikes panicle & & $0.56 * / 0.04$ & - & $0.48 * / 0.22$ & - & - \\
\hline Tillers ramet & & & & $0.68 * / 0.81 *$ & $0.04 / 0.56^{*}$ & - \\
\hline$\%$ reproductive & & & & & & \\
\hline tillers & & & & $0.85 * / 0.58 *$ & - & - \\
\hline Spikes ramet $^{-1}$ & & & & & $0.31 / 0.55^{*}$ & - \\
\hline Seeds ramet ${ }^{-1}$ & & & & & & - \\
\hline
\end{tabular}

given that sideoats grama occurs in the area between the sites, that many native herbivores are able to reach both sites, and that genotypes from the grazed population exhibit vegetative characteristics that are consistent with selection for tolerance to defoliation (Briske 1996), it appears reasonable to speculate that exposure to livestock may have affected reproductive characteristics of the grazed population.

As in this research, Scott and Whalley (1984) found that plants from populations of Danthonia linkii Kunth and D. richard sonii Cashmore that had been exposed to intense grazing by sheep produced fewer seeds per panicle on average when grown without defoliation stress compared to plants from populations from sites with lower grazing stress. These results are also consistent with the observation that increased seed production to expand the seed bank is apparently not a common mechanism of defoliation resistance in perennial caespitose grasses (Pyke 1990).

Reduced average seed production potential per plant in the grazed population is due in part to a combination of traits that lead to a reduction in overall plant size. These include a reduced number of tillers and panicles compared to the ungrazed population (Table 1). This morphology and its effects on seed production is consistent with findings from previous research on the evolution of grazing-adapted morphotypes in caespitose grasses (e.g., Detling and Painter 1983, Painter et al. 1989, 1993). These morphological adaptations affecting seed production may therefore represent simply secondary consequences of strong selection for vegetative traits associated with defoliation tolerance. 
The observation of reduced floral fertility (number of seeds per spike) in the grazed population suggests that selection under grazing stress may have affected the production of seeds within an individual spikelet. This could be driven by competitive advantages afforded to genotypes that allocate additional photosynthetic resources to vegetative growth and less to seed production (Bazzaz et al. 1987, Ashman 1994). Physiological trade-offs of this sort (Stearns 1992) would be expected to lead to negative correlations between the life-history traits affected although these have been difficult to document in perennial grasses (Reekie 1991, Cheplick 1995). While this research was not designed to identify physiological tradeoffs, there is some evidence for such a trade-off in the ungrazed population where the number of tillers per plant is negatively correlated with the number of caryposes per spike (Table 2). However, this is not conclusive since seed production traits are not correlated with the number of spikes produced either by individual panicles or whole plants in this population as might be expected with this trade-off.

A commonly discussed physiological trade-off related to seed production involves linkage of decreases in seed number per plant with increases in seed mass, and with increases in the latter trait presumably leading to improved seedling establishment (Westoby et al. 1992). This does not appear to be the case here as mean seed mass did not differ between the populations and this trait was not correlated with any components of seed output (Table 2).

Available evidence suggests that the polyploid sideoats grama populations native to southern Arizona are facultatively apomictic (Harlan 1949, Freter and Brown 1955, Gould 1951). The existence of facultative apomixis and complex sexual/apomictic cycles (Richards 1986) in this taxon would seem likely given current understanding of its reproductive biology. Recent research (Overath and Asmussen 1998) suggests that it may be incorrect to assume that populations of facultatively apomictic plants are necessarily depauperate genetically and therefore less responsive to selection than non-apomictic species. Canfield (1957) showed that individual sideoats grama plants did not live longer than 3 years on sites grazed by cattle in southern Arizona. Together, these findings indicate that significant genetic variation may have existed and sufficient mortality and seedling establishment could have occurred to permit selection of traits associated with grazing resistance in the grazed population in the roughly 100 years that it has been exposed to livestock.

Reduced seed production would have negative consequences most noticeably in reducing propagules available for colonization of open sites (Richards 1990). Reduced seed production as demonstrated here could also affect genetic structure within the grazed population since the production of fewer seeds would result in reduced opportunities for sexual reproduction should it occur. Indeed, previous genetic analyses of these 2 populations (Smith 1998) suggests that the grazed population is less variable genetically in vegetative traits associated with defoliation tolerance. The grazed population may therefore be more susceptible to local extinction (O'Conner 1991) due to either the direct demographic effects of reduced contribution to the soil seed bank, or to the more indirect genetic effect of limiting available genetic variability due to reduced potential for outcrossing.

\section{Literature Cited}

Aarssen, L.W. and R. Turkington. 1985. Within-species diversity in natural populations of Holcus lanatus, Lolium perenne and Trifolium repens from four different-aged pastures. J. Ecol. 73: 869-886.

Ashman, T.-L. 1994. A dynamic perspective on the physiological cost of reproduction in plants. Amer. Nat. 144:300-316.

Bazzaz, F.A., N.R. Chiariello, P.D. Coley, and L.F. Pitelka. 1987. Allocating resources to reproduction and defense. BioScience 37:58-67.

Briske, D.D. 1996. Strategies of plant survival in grazed systems: A functional interpretation, p. 37-67. In: J. Hodgson (ed.), The ecology and management of grazing systems. Oxford Univ Press, New York, N.Y.

Briske, D.D. and J.H. Richards. 1995. Plant response to defoliation: A physiological, morphological and demographic evaluation, $\mathrm{p}$. 635-710. In: D.J. Bedunah and R.E. Sosebee (eds.), Wildland plants: Physiological ecology and developmental morphology. Soc. Range Manage., Denver, Colo.

Brown, D.E. 1994. Semidesert grasslands, p. 123-135. In: D. E. Brown (ed.), Biotic communities: southwestern United States and northwestern Mexico, University of Utah Press, Salt Lake City, Ut.

Canfield, R.H. 1957. Reproduction and life span of some perennial grasses of southern Arizona. J. Range Manage. 10:199-203.

Carmen, J.G. and D.D. Briske. 1985. Morphologic and allozymic variation between long-term grazed and non-grazed populations of the bunchgrass Schizachyrium scoparium var. frequens. Oecologia 66:332-337.
Cheplick, G.P. 1995. Life history trade-offs in Amphibromus scabrivalis (Poaceae): Allocation to clonal growth, storage, and cleistogamous reproduction. Amer. J. Bot. 82:621-629.

Cronquist, A., A.H. Homgren, N.H. Holmgren, J.L. Reveal, and P.A. Holmgren. 1977. Intermountain Flora. Vascular plants of the Intermountain West, U.S.A. Columbia University Press, New York, N.Y.

Detling, J.K. and E.L. Painter. 1983. Defoliation responses of western wheatgrass populations with diverse histories of prairie dog grazing. Oecologia 57: 65-71.

Freter, L.E. and W.V. Brown. 1955. A cytotaxonomic study of Bouteloua curtipendula and B. uniflora. Bull. Torr. Bot. Club 82:121-130.

Gordon, I.L. 1979. Standard errors of heritabilities based on perennial observations, with application to Yorkshire fog grass. Euphytica 28:81-88.

Gould, F.W. 1951. Notes on apomixis in sideoats grama. J. Range Manage. 12:25-28.

Gould, F. W. and Z. J. Kapadia. 1964. Biosystematic studies in the Bouteloua cur tipendula complex II. Taxonomy. Brittonia 16:182-207.

Hadley, D., P. Warshall, and D. Bufkin. 1991. Environmental change in Aravaipa, 1870-1970: an ethnoecological survey. Cultural Resource Series 7, Ariz. Bureau of Land Management, Phoenix, Ariz.

Harlan, J.R. 1949. Apomixis in side-oats grama. Am. J. Bot. 36:495-499.

Hoffmeister, D. F. 1986. Mammals of Arizona. University of Arizona Press, Tucson, Ariz.

Krausman, P. R., A. J. Kuenzi, R. C. Etchberger, J. R. Rautenstrauch, L. L. Ordway, and J. J. Hervert. 1997. Diets of desert mule deer. J. Range Manage. 50:513-522.

Littell, R.C., G.A. Milliken, W.W. Stroup, and R.D. Wolfinger. 1996. SAS System for Mixed Models. SAS Institute, Inc., Cary, N.C.

Lynch, M. and B. Walsh. 1998. Genetics and analysis of quantitative traits. Sinauer Associates, Inc., Sunderland, Mass.

Nyquist, W.E. 1991. Estimation of heritability and prediction of selection response in plant populations. Critical Rev. in Plant Sci. 10:235-322.

O'Connor, T.G. 1991. Local extinction in perennial grasslands: A life-history approach. Amer. Natur. 137:753-773.

Orodho, A.B., R.L. Cuany, and M.J. Trlica. 1998. Previous grazing or clipping affects seed of Indian ricegrass. J. Range Manage. 51:37-41.

Overath, R.D. and M.A. Asumssen. 1998. Genetic diversity at a single locus under viability selection and facultative apomixis: Equilibrium structure and deviations from Hardy-Weinberg frequencies. Genetics 148:2029-2039. 
Painter, E.L., J.K. Detling, and D.A. Steingraeber. 1989. Grazing history, defoliation, and frequency-dependent competition: effects on two North American grasses. Amer. J. Bot. 76: 1368-1379.

Painter, E.L., J.K. Detling, and D.A. Steingraeber. 1993. Plant morphology and grazing history: Relationships between native grasses and herbivores. Vegetatio 106:37-62.

Pyke, D.A. 1990. Comparative demography of co-occurring introduced and native tussock grasses: persistence and potential expansion. Oecologia 82:537-543.

Reekie, E.G. 1991. Cost of seed versus rhizome production in Agropyron repens. Can. J. Bot. 69:2678-2683.
Richards, A.J. 1986. Plant Breeding Systems. Allen \& Unwin, London.

Richards, A.J. 1990. The implications of reproductive versatility for the structure of grass populations. p. 131-153. In: G.P. Chapman (ed.), Reproductive versatility in the grasses. Cambridge Univ. Press, Cambridge.

Scott, A.W. and R.D.B. Whalley. 1984. The influence of intensive sheep grazing on genotypic differentiation in Danthonia linkii, D. richardsonii and D. racemosa on the New England tablelands. Aust. J. Ecol. 9:419-429.

Sokal, R.R. and F.J. Rohlf. 1995. Biometry. $3^{\text {rd }}$ ed. W.H. Freeman, New York, N.Y.
Smith, S.E. 1998. Variation in response to defoliation between populations of Bouteloua curtipendula var. caespitosa (Poaceae) with different livestock grazing histories. Amer. J. Bot. 85:1266-1272.

Stearns, S.C. 1992. The evolution of life histories. Oxford Univ. Press, Oxford.

Trlica, M.J. and A.B. Orodho. 1989. Effects of protection from grazing on morphological and chemical characteristics of Indian ricegrass, Oryzopsis hymenoides. Okios 56:299-308.

Westoby, M., E. Jurado, and M. Leishman. 1992. Comparative evolutionary ecology of seed size. Trends in Ecol. and Evol. $7: 368-372$.

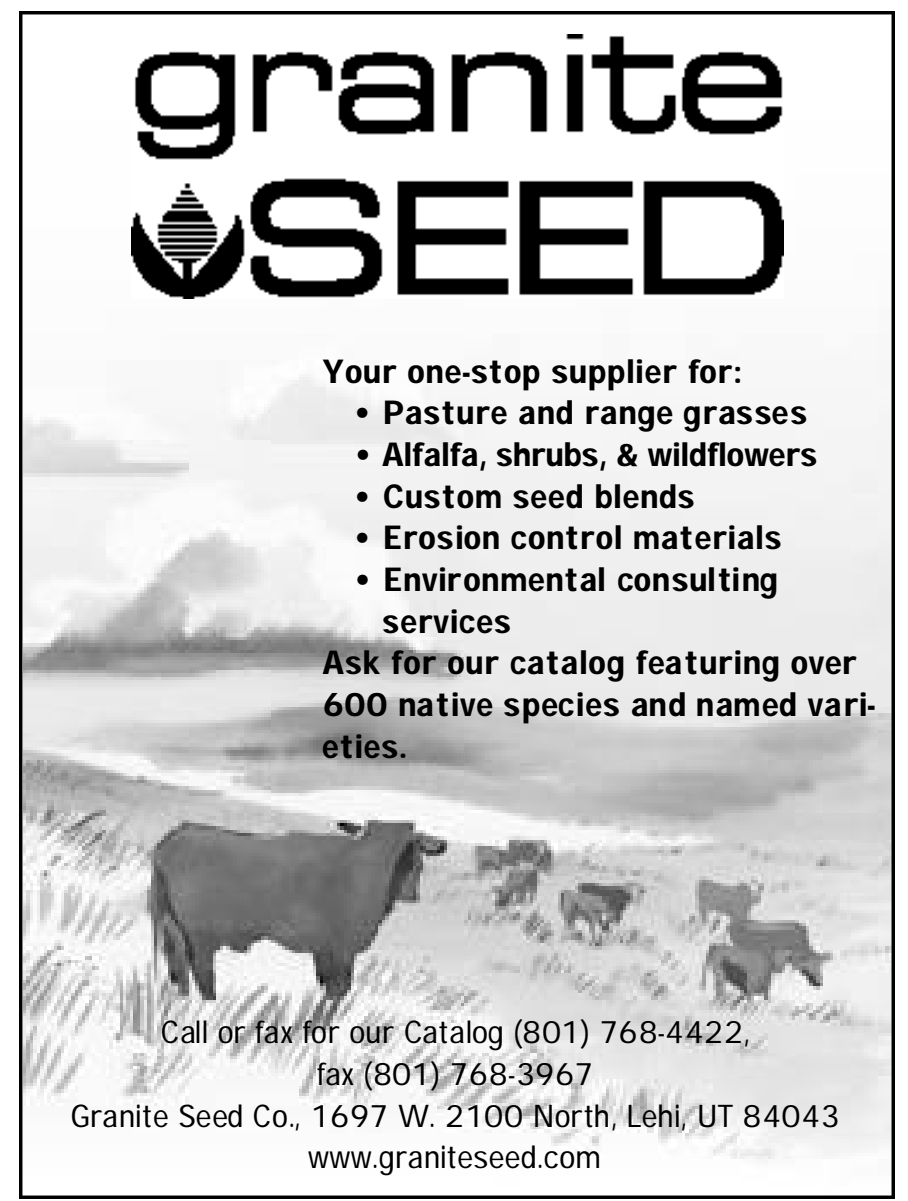

